\title{
Epithelial adhesive junctions
}

\section{Christopher T. Capaldo, Attila E. Farkas and Asma Nusrat*}

\author{
Address: Epithelial Pathobiology Research Unit, Department of Pathology, Emory University, 615 Michael Street, Atlanta, GA 30322, USA \\ *Corresponding author: Asma Nusrat (anusrat@emory.edu) \\ Fl000Prime Reports 2014, 6:I (doi:10.12703/P6-I) \\ This is an open-access article distributed under the terms of the Creative Commons Attribution-Non Commercial License \\ (http://creativecommons.org/licenses/by-nc/3.0/legalcode), which permits unrestricted use, distribution, and reproduction in any medium, \\ provided the original work is properly cited. You may not use this work for commercial purposes. \\ The electronic version of this article is the complete one and can be found at: http://fl000.com/prime/reports/b/6/I
}

\begin{abstract}
Epithelial adhesive cell-to-cell contacts contain large, plasma membrane-spanning multiprotein aggregates that perform vital structural and signaling functions. Three prominent adhesive contacts are the tight junction, adherens junction, and the desmosome. Each junction type has unique cellular functions and a complex molecular composition. In this review, we comment on recent and exciting advances in our understanding of junction composition and function.
\end{abstract}

\section{Too tight to see}

Tight junction (TJ) structures form a gasket-like seal around the cell at the apical-most aspect of the lateral plasma membrane (Figure 1) [1-4]. This seal regulates both the intermixing of apical and lateral membrane components and paracellular tissue barrier properties. TJs are responsible for both maintaining epithelial polarity and restricting the paracellular passage of ions and solutes. By freeze-fracture electron microscopy, the ultrastructure of the $\mathrm{TJ}$ is seen as a latticework of proteinaceous strands. It has been appreciated for some time that these stands contain claudin superfamily proteins, yet due to the lack of a claudin crystal structure, little is known concerning primary claudin interactions in TJ strands. Suzuki et al. recently provided a compelling model of the TJ structure [5]. The flagellate protist Euglena gracilis utilizes the claudin-like protein IP39 to form linear arrays that are quite similar to TJs. Purification and crystallization of endogenous IP39 arrays led to several discoveries: a) polymerization of trimeric IP39 subunits, b) antiparallel row formation, and c) heterogeneous trimer interactions, which suggest a potential mechanism for TJ strand branching.

The TJ is by far the most complex and least understood junction, due in part to the diversity and number of its molecular constituents. Indeed, discoveries of novel TJ-associated proteins continue. For example, Higashi et al. introduced the angulin family of tricellular TJ proteins [6].
The authors studied the function of lipoprotein receptor (LSR)-related proteins immunoglobulin-like domaincontaining receptor1 (ILDR1) and 2, which exhibit tissueand organ-specific expression patterns and have differing effects on barrier function, with ILDR1 and LSR being associated with tighter barriers than ILDR2. Tricellular TJ contacts occur as three cells intersect, and attempts to inventory tricellular proteins are particularly welcome given that paracellular macromolecule flux occurs largely through these contacts [7]. Prior to this finding, only tricellulin and LSR were known components of the tricellular junction.

Our growing knowledge of TJ constituents presents a further problem: how do the plethora of TJ proteins interact? Van Itallie et al. address this issue by assessing the protein complexes surrounding zonula occludens-1 (ZO-1) [8]. Using a biotin ligase proximity-labeling technique, the authors identify more than 400 potential interacting proteins, including novel TJ proteins FBP1L, US6NL, and IGS11. Truncation studies showed the ZO-1 $\mathrm{N}$-terminal segments interact in proximity to signaling proteins and transmembrane components, such as claudins and occludin, while C-terminal ZO-1 interacts with actin network proteins. Therefore, ZO-1, either individually or in mass, links the transmembrane TJ components to the actin cytoskeleton. This powerful technique has the potential to help us understand the nature and function of the TJ plaque, particularly under 
Figure I. Epithelial cell-cell junctions

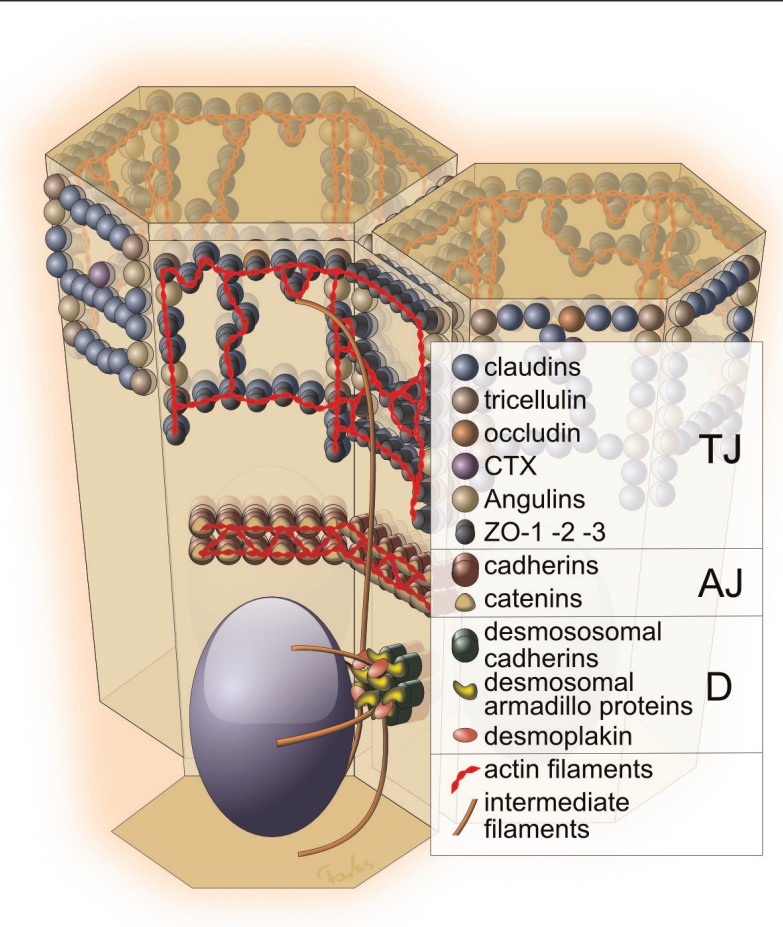

Adhesive contacts are shown as a tight junction (TJ), adherens junction (AJ), and desmosome (D). Each contact consists of transmembrane, cytosolic plaque, and cytoskeletal constituents.

different biologically interesting states, such as TJ assembly or remodeling due to proinflammatory cytokine exposure.

\section{Adhesion under stress}

Cadherin-based adhesions populate the lateral membrane below the TJ, forming homotypic transcellular interactions through their calcium-dependent ectodomains. E-cadherin is a major cadherin isoform in epithelial tissues and is involved in cellular processes such as cell-cell contact inhibition signaling, cell proliferation, actin cytoskeletal remodeling, and cell polarity establishment $[9,10]$. Inside the cell, E-cadherin binds to the catenin family proteins p120, $\alpha$-catenin, and $\beta$-catenin. Catenins mediate cadherin-dependent functions, and the nature of the molecular mechanisms involved is the subject of intense study and debate.

A recent article by Rangarajan and Izard weighs in on this debate with an interesting comparative structural study of full-length $\alpha$-catenin [11]. The $\beta$-catenin- $\alpha$-catenin complex does not appear to directly bind F-actin, and, therefore, a physical link between the adherens junction (AJ) and actin network is believed to require additional interactions $[12,13]$.
The authors observe that $\alpha$-catenin forms an asymmetric dimer with a high affinity for F-actin, while the $\beta$-catenin$\alpha$-catenin complex binding interface competes for both the $\alpha$-catenin dimerization domain and F-actin engagement. The authors further suggest that activated vinculin binding may mediate the link between E-cadherin and the actin network.

Several notable studies have recently reinforced the concept of a direct linkage between the AJ and the actin cytoskeleton through $\alpha$-catenin, including studies of $\alpha$-catenin function in Drosophila. Desai et al. take a mutagenesis approach and provide in vivo data supporting the view that $\alpha$-catenin is a physical linker between the cadherin- $\beta$-catenin complex and the actin cytoskeleton [14]. In Drosophila, Rap1 activity has been shown to regulate cadherin-catenin interactions with the actin cytoskeleton during gastrulation, further supporting this link [15].

Using single-molecule atomic force microscopy, Rakshit et al. studied cadherin homodimer bonding under mechanical tension [16]. The authors showed that newly formed E-cadherin trans-dimers will rapidly form a "catch bond", which is strengthened under stress. Persistent E-cadherin trans-dimers will mature and exhibit high-affinity binding in the absence of force. These results suggest a physical mechanism that cadherins use to resist tensile forces as cells rearrange during cell-cell contact formation and tissue homeostasis.

These recent structural and biochemical findings exploring the $\mathrm{AJ}$ are fascinating, and given that both $\alpha$-catenin and vinculin have recently been shown to act as tensionregulated adaptor proteins, it seems likely that the cadherin-catenin complex functions as a mechanical adhesion stress sensor $[17,18]$. If so, controversies surrounding the biochemical arrangement of this complex may require the study of adhesions under stress.

\section{Desmosome in the Spotlight}

Desmosomes form intermittent spot adhesions along the lateral membrane and are anchored in the cytoplasm to intermediate filaments. These structures provide mechanical resilience to the epithelium, thus contributing to tissue homeostasis. There are two types of desmosomal cadherins, desmogleins (1-4) and desmocollins (1-3), each with several isoforms (for detailed desmosome structure, see [19]). Along with their structural role, desmosomes are emerging as centers of intracellular signaling.

desmoglein-1 appears in recent studies as a regulator of cell differentiation. The guanylate exchange factor Bcr is a regulator of keratinocyte differentiation that acts 
through myocardin-related transcription factor/serum response factor (MAL/SRF). Knockdown of Bcr or MAL impairs differentiation and downregulates desmoglein-1 transcription, both of which can be rescued by desmoglein-1 expression [20]. A novel link between desmoglein-1 and differentiation has been demonstrated through the interaction of desmoglein-1 with erbin, a known regulator of extracellular signalregulated kinase (ERK) signaling [21]. Loss of desmocollin-2 increased proliferation and enables tumor growth via Akt/ $\beta$-catenin signaling, suggesting that desmocollin-2 is a tumor suppressor [22]. A further link has been found between desmosomes and proliferation through Akt signaling and plakophilin-1 [23]. Similarly, desmocollin-3 has been identified as a tumor suppressor that inhibits epidermal growth factor (EGF) or ERK signaling in lung cancer cells [24]. Two recent studies report crosstalk between the desmosome and AJ. On loss of the AJ component, $\beta$-catenin induces increased $\gamma$-catenin expression and translocation to the AJ substituting for $\beta$-catenin structural function, but not $\mathrm{T}$ cell factor/lymphoid enhancing factor (TCF/Lef) transcriptional activity [25]. In desmoglein-3-depleted head and neck cancer cell lines, $\gamma$-catenin translocates from the desmosome to the nucleus bound to TCF and inhibited TCF/Lef transcriptional activity [26]. Desmoglein-3 has recently been found to be clustered by plakophilin 1 [27]. A novel desmosomal constituent, p53 apoptosis effector related to PMP-22 or PERP, has recently been found to be ubiquitously expressed in epithelial tissues and is a newly characterized constituent of desmosomal junctions and possibly AJs [28].

Keratin intermediate filaments link to desmosomal junctions and provide structural integrity to the tissue, but keratin also stabilizes desmosomes through keratin-Rack1 interaction, which blocks protein kinase $\mathrm{C}$ (PKC)- $\alpha$-mediated desmoplakin phosphorylation and subsequent endocytosis of desmosomal proteins [29]. Knockout of the dominant keratin pair of the upper epidermis, keratin 1 and 10, not only disrupts desmosome structure but also causes premature loss of nuclei [30].

Similar to the AJ protein E-cadherin, the desmosomal cadherins are cleaved by intracellular and extracellular proteases, and the resulting soluble fragments affect epithelial function (for review, see [31]). The above studies point to functional similarities between the three junctions as mediators of cell-cell contact signaling.

\section{Conclusions}

Rapid progress is being made in the exploration of cell adhesive junctions, and given the central role these junctions play in epithelial homeostasis and disease, the attention is warranted. Many of these complexes have been studied for decades but retain the ability to surprise us with novel biological functions, protein constituents, and links to disease states. That said, we expect more surprises in the years to come.

\section{Abbreviations}

AJ, adherens junction; EGF, epidermal growth factor; ERK, extracellular signal-regulated kinase; ILDR, immunoglobulin-like domain-containing receptor; LEF, lymphoid enhancing factor; LSR, lipoprotein receptor; $\mathrm{MAL}$, myocardin-related transcription factor; $\mathrm{PKC}$, protein kinase C; TCF, T cell factor; TJ, tight Junction; ZO-1, zonula occludens-1.

\section{Disclosures}

The authors declare that they have no disclosures.

\section{References}

I. Tsukita $S$, Furuse $M$, Itoh $M$ : Multifunctional strands in tight junctions. Nat Rev Mol Cell Biol 200I, 2:285-93.

2. Ivanov Al, Naydenov NG: Dynamics and regulation of epithelial adherens junctions: recent discoveries and controversies. Int Rev Cell Mol Biol 2013, 303:27-99.

3. Brooke MA, Nitoiu D, Kelsell DP: Cell-cell connectivity: desmosomes and disease. J Pathol 20I2, 226:I58-7I.

4. Saito M, Tucker DK, Kohlhorst D, Niessen CM, Kowalczyk AP: Classical and desmosomal cadherins at a glance. J Cell Sci 20 I2, I 25:2547-52.

5. Suzuki H, Ito $Y$, Yamazaki Y, Mineta K, Uji M, Abe K, Tani K, Fujiyoshi $Y$, Tsukita S: The four-transmembrane protein IP39 of Euglena forms strands by a trimeric unit repeat. Nat Commun 20I3, 4:1766.

FlOOOPrime RECOMMENDED

6. Higashi T, Tokuda S, Kitajiri S, Masuda S, Nakamura H, Oda Y, Furuse M: Analysis of the 'angulin' proteins LSR, ILDRI and ILDR2-tricellulin recruitment, epithelial barrier function and implication in deafness pathogenesis. J Cell Sci 2013, I26:966-77.

FlOOOPrime

RECOMMENDED

7. Krug SM, Amasheh S, Richter JF, Milatz S, Günzel D, Westphal JK, Huber O, Schulzke JD, Fromm M: Tricellulin forms a barrier to macromolecules in tricellular tight junctions without affecting ion permeability. Mol Biol Cell 2009, 20:3713-24.

\section{FlOOOPrime}

\section{RECOMMENDED}

8. van Itallie CM, Aponte A, Tietgens AJ, Gucek M, Fredriksson K, Anderson JM: The $\mathbf{N}$ and $\mathbf{C}$ termini of ZO-I are surrounded by distinct proteins and functional protein networks. J Biol Chem 20।3, 288: |3775-88.

FlOOOPrime
RECOMMENDED

9. Maître J, Heisenberg C: Three functions of cadherins in cell adhesion. Curr Biol 2013, 23:R626-33.

FlOOOPrime RECOMMENDED

10. Kim N, Koh E, Chen X, Gumbiner BM: E-cadherin mediates contact inhibition of proliferation through Hippo 
signaling-pathway components. Proc Natl Acad Sci USA 201I, 108: 1 1930-5.

\section{FlOOOPrime}

II. Rangarajan ES, Izard T: Dimer asymmetry defines $\alpha$-catenin interactions. Nat Struct Mol Biol 2013, 20:188-93.

\section{FlOOOPrime}

12. Drees F, Pokutta S, Yamada S, Nelson WJ, Weis WI: Alphacatenin is a molecular switch that binds E-cadherin-betacatenin and regulates actin-filament assembly. Cell 2005, | 23:903-| 5 .

\section{FlOOOPrime RECOMMENDED}

13. Weis WI, Nelson WJ: Re-solving the cadherin-catenin-actin conundrum. J Biol Chem 2006, 28 I:35593-7.

\section{FlOOOPrime RECOMMENDED}

14. Desai R, Sarpal R, Ishiyama N, Pellikka M, Ikura M, Tepass U: Monomeric $\alpha$-catenin links cadherin to the actin cytoskeleton. Nat Cell Biol 2013, 15:261-73.

\section{FlOOOPrime} RECOMMENDED

15. Wang Y, Khan Z, Wieschaus EF: Distinct RapI activity states control the extent of epithelial invagination via $\alpha$-catenin. Dev Cell 2013, 25:299-309.

\section{FlOOOPrime}

\section{RECOMMENDED}

16. Rakshit S, Zhang Y, Manibog K, Shafraz O, Sivasankar S: Ideal, catch, and slip bonds in cadherin adhesion. Proc Natl Acad Sci USA 2012, 109:18815-20.

\section{FlOOOPrime \\ RECOMMENDED}

17. Yonemura S, Wada Y, Watanabe T, Nagafuchi A, Shibata M: alphaCatenin as a tension transducer that induces adherens junction development. Nat Cell Biol 2010, 12:533-42.

\section{FlOOOPrime}

\section{RECOMMENDED}

18. Grashoff C, Hoffman BD, Brenner MD, Zhou R, Parsons M, Yang MT, McLean MA, Sligar SG, Chen CS, Ha T, Schwartz MA: Measuring mechanical tension across vinculin reveals regulation of focal adhesion dynamics. Nature 2010, 466:263-6.

\section{FlOOOPrime}

19. Nekrasova O, Green KJ: Desmosome assembly and dynamics. Trends Cell Biol 20I3.

\section{FlOOOPrime}

20. Dubash AD, Koetsier JL, Amargo EV, Najor NA, Harmon RM, Green KJ: The GEF Bcr activates RhoA/MAL signaling to promote keratinocyte differentiation via desmoglein-I.j Cell Biol 20I3, 202:653-66.

\section{FlOOOPrime} RECOMMENDED

21. Harmon RM, Simpson CL, Johnson JL, Koetsier JL, Dubash AD, Najor NA, Sarig O, Sprecher E, Green KJ: Desmoglein-I/Erbin interaction suppresses ERK activation to support epidermal differentiation. J Clin Invest 2013, I23:1556-70.

\section{FIOOOPrime}

22. Kolegraff K, Nava P, Helms MN, Parkos CA, Nusrat A: Loss of desmocollin-2 confers a tumorigenic phenotype to colonic epithelial cells through activation of $A k t / \beta$-catenin signaling. Mol Biol Cell 20II, 22:II2I-34.

23. Wolf $A$, Rietscher $K$, Glaß M, Hüttelmaier $S$, Schutkowski $M$, Ihling C, Sinz A, Wingenfeld A, Mun A, Hatzfeld M: Insulin signaling via Akt2 switches plakophilin I function from stabilizing cell adhesion to promoting cell proliferation. / Cell Sci 2013, I 26: | $832-44$

\section{FIOOOPrime}

\section{RECOMMENDED}

24. Cui T, Chen Y, Yang L, Knösel T, Huber O, Pacyna-Gengelbach M, Petersen I: The p53 target gene desmocollin 3 acts as a novel tumor suppressor through inhibiting EGFR/ERK pathway in human lung cancer. Carcinogenesis 2012, 33:2326-33.

\section{FlOOOPrime}

RECOMMENDED

25. Wickline ED, Du Y, Stolz DB, Kahn M, Monga SPS: $\gamma$-Catenin at adherens junctions: mechanism and biologic implications in hepatocellular cancer after $\beta$-catenin knockdown. Neoplasia 2013, 15:42I-34.

\section{FlOOPrime}

\section{RECOMMENDED}

26. Chen Y, Lee L, Chao Y, Chang JT, Lu Y, Li H, Chiu C, Li Y, Li Y, Chiou J, Cheng A: DSG3 facilitates cancer cell growth and invasion through the DSG3-plakoglobin-TCF/LEF-Myc/cyclin DI/MMP signaling pathway. PLOS ONE 2013, 8:e64088.

\section{FIOOOPrime}

27. Tucker DK, Stahley SN, Kowalczyk AP: Plakophilin-I Protects Keratinocytes from Pemphigus Vulgaris IgG by Forming Calcium-Independent Desmosomes. J Invest Dermatol 2013.

\section{FlOOOPrime}

28. Franke WW, Heid H, Zimbelmann R, Kuhn C, Winter-Simanowski S, Dörflinger Y, Grund C, Rickelt S: Transmembrane protein PERP is a component of tessellate junctions and of other junctional and non-junctional plasma membrane regions in diverse epithelial and epithelium-derived cells. Cell Tissue Res 2013, 353:99-1115.

\section{FlOOOPrime}

\section{RECOMMENDED}

29. Kröger C, Loschke F, Schwarz N, Windoffer R, Leube RE, Magin TM Keratins control intercellular adhesion involving PKC $\alpha$-mediated desmoplakin phosphorylation. J Cell Biol 2013, 201:68I-92.

\section{FlOOPrime}

\section{RECOMMENDED}

30. Wallace L, Roberts-Thompson L, Reichelt J: Deletion of $\mathbf{K I / K I O}$ does not impair epidermal stratification but affects desmosomal structure and nuclear integrity. J Cell Sci 20I2, I25: 1750-8.

\section{FlOOOPrime}

\section{RECOMMENDED}

31. Nava P, Kamekura R, Nusrat A: Cleavage of transmembrane junction proteins and their role in regulating epithelial homeostasis. tissuebarriers 2013, I:e24783. 